\title{
The Influence of Venture Capital Investment on Underpricing of Second-Board Market IPO
}

\author{
Ling Wu \\ Department of Economics, Jinan University, Guangzhou, China \\ Email: wuling_sh@163.com
}

How to cite this paper: Wu, L. (2017). The Influence of Venture Capital Investment on Underpricing of Second-Board Market IPO. Journal of Financial Risk Management, 6, 37-47.

https://doi.org/10.4236/jfrm.2017.61004

Received: January 9, 2017

Accepted: March 7, 2017

Published: March 10, 2017

Copyright $\odot 2017$ by author and Scientific Research Publishing Inc. This work is licensed under the Creative Commons Attribution International License (CC BY 4.0).

http://creativecommons.org/licenses/by/4.0/

\begin{abstract}
This study introduces venture capital investment as a variable in underpricing of stock's IPO. From the theoretical perspective, this study uses four points of view-Certification, Supervision, Adverse selection and Grandstanding theory, to explain the relationship of venture capital investment and underpricing of IPO. In real empirical part, this study takes 125 second-board companies as a sample to research on the relationship among venture capital investment, the characteristics of venture capital and underpricing of IPO. The finding shows that in the second-board market, companies which have venture capital institutions involved show a higher IPO underpricing rate compared to the companies which have no venture capital institutions involved. The main finding is that there is irrational investment behavior in the market.
\end{abstract}

\section{Keywords}

Venture Capital, Second-Board Market, IPO Underpricing

\section{Introduction}

As of the end 2014, there are more than 400 companies listed on second-board market, which have provided a new financing channel for many innovative small and medium-sized enterprises. The IPO underpricing refers to the phenomenon that closing price higher than the issue price in First-day. Among the first batch of 28 second-board market listed companies, the average underpricing rate is $106.23 \%$, the highest up to $209.73 \%$. The high underpricing level will attract people to purchase new shares, then use pricing discrepancies to arbitrage, thus have negative effects on fund allocation of capital market.

Venture capital investment refers to a way of operation that the venture capital institutions invest innovative small and medium-sized enterprises in the form of purchasing shares, then, venture capital institutions participate the company's 
management to help it up to the IPO standard, after the company have positive profits, its share price will rise and the venture capital institutions will sell the shares to get a capital gain. On the one hand, venture capital investment promoted the normal operation of second-board market, and became an important channel to solute financing difficulty of many small and medium-sized enterprises. On the other hand, second-board market provided the best exit channel for venture capital; it made venture capital get involved in the capital market to promote innovative small and medium-sized enterprises' development.

\section{Literature Review}

\subsection{Certification Theory}

Certification Theory is earliest proposed by American scholar Megginson \& Weisss (1991). he called the positive tension that venture capital produced to IPO enterprises as Certification Theory-like underwriter, venture capital have the third party certification effect on IPO enterprises. As a shareholder, venture capital institution will convey honesty information to public in order to protect its reputation. So, if a company have venture capital institution as its stockholder, public investors will see it as a signal of high-quality company. This make the involvement of venture capital institution can reduce the degree of information asymmetry between company and investors and help investors know more about the company's true value, then reduce the underpricing rate.

\subsection{Supervision Theory}

Barry et al. (1990) think if venture capital institutions with high proportion share and occupying a certain seat on the board will play a supervisory role in the company. It can make the underpricing degree of the companies which have venture capital involved is lower than the companies which don't have venture capital involved. Barry C. B. called this phenomenon as Supervision Theory and it is a supplement to the Certification Theory. On the one hand, in order to protect their own interests, venture capital institution will pay close attention to the operating conditions of the invested enterprise. On the other hand, risk investment institutions can influence on the operating decision through its holdings of shares and the rights of the board, then play a supervision role in the enterprise.

\subsection{Adverse Selection Theory}

In 1990, Amit, Glosteii and Muller (1990) first introduce "Adverse selection Theory" to IPO underpricing. In this theory, there is exist information asymmetry between venture capital institutions and enterprise,-as an outside investor, the information venture capital institutions grasped can not comprehensive and true, and it may cause deviation when evaluated the enterprise. In fact, this situation may cause the enterprises which venture capital institutions involved are not high-quality enterprises, so these enterprises tend to choose a lower issuance price and caused a higher underpricing rate. 


\subsection{Grandstanding Theory}

American scholar Gompers (1996) proposed the Gradstanding Theory. In his finding, compared to the enterprises which immature venture capital institutions involved in, the enterprises which mature venture capital institutions involved in shows a lower underpricing rate and have a better performance in other IPO indexes. Gompers think the reason of this phenomenon is venture capital institutions need to raise money to maintain operations, but most of the new venture capital institutions are lack of high reputation, in order to raise more funds in the future, these institutions are crying out for success projects to enhance reputation in capital market. So these enterprises that immature venture capital institutions involved don't choose the best opportunity to go public, leading to the higher underpricing rate and dismal performance.

\section{Research Methodology}

\subsection{Sample's Selection and Data Sources}

This study selected a total of 125 the second-board market listed companies from 2012 to 2014 as sample. Through consulting the stockholder list in prospectus to check whether there exists venture capital institutions and its proportion of shareholding. All the prospectus are down from can explain this source a little bit? Other data like IPO underpricing, IPO P/E ratio, turnover rate are from explain a little bit? it is a database created by some investment firm from my memory. This study dividing these 125 companies into two sub-sample: VC-Backed and NON-VC-Backed, then dividing "VC-Backed" sample into two groups: VC-Rep-High and VC-Rep-Low. Specific steps are as follows: first, look up the keyword like investment, venture investment, innovational investment in prospectus, if the company's shareholders including venture capital institutions, it will be classification to "VC-Backed" sample, otherwise will be classification to "NON-VC-Backed" sample. Second, refer to the China venture capital and private equity annual ranking 2014 by Zero2IPO Group, the companies which in the list of "the ranking might be different from 2012 to 2014, why using 2014 and "Top 20 VC Firms of the Year 2014 (China)", the study classified these companies into "VC-Rep-High". After classified the 125 companies, the subsample "VC-Backed" size is 105, sub-sample "NON-VC-Backed" size is 20, in the sub-sample "VC-Backed", the sample size of "VC-Rep-High" is 14 and the sample size of "VC-Rep-Low" is 91.

\subsection{Variables' Selection and Explanation}

\subsubsection{Explained Variables' Selection and Explanation}

This study selected IPO underpricing as explained variable. In consideration of the influence of market quotation on IPO underpricing, this study chooses the adjusted IPO underpricing (AUp) as explained variable.

$$
\mathrm{AUp}=\frac{P_{1}-P_{0}}{P_{0}}-\frac{M_{1}-M_{0}}{M_{0}}
$$


In the above formula, can you explain this formula a little bit, any theory backup or reason?, P1 refers to the first-day closing price, P0 refers to the IPO price, M1 refers to the second-board closing index of first trading day, M0 refers to the second-board closing index of issue day.

\subsubsection{Explaining Variables' Selection and Explanation}

Would be better if there is some summary table of ALL variables, to give us a general picture of the dataset.

First, the participation of venture capital institutions. In this study, the companies in sub-sample "VC-Backed" average value of 1 .

Second, the reputation of venture capital institutions. The companies in subsample "VC-Rep-High" average value of 1 .

Third, the quantity of venture capital institutions. If the company's shareholders including more than one institution, the fraud cases will be decreased in some degree.

Fourth, total shareholding ratio of venture capital institutions?. The total shareholding ratio will send secondary market investors a message-the higher shareholding ratio refers to the higher reduction ratio of shareholders, thus, small investors will face the bigger risk and give the share lower valuations.

\subsubsection{Control Variables Selected and Explanation}

IPO underpricing can be influenced by various factors. Except for venture capital institutions, this study uses three other factors-basic status of the company, market performance and shareholders' profitability to select appropriate indexes, the specific indexes are as follow:

First, operation time. This variable refers to the year from company's establish to the stock be listed. To a certain extent, company's operation years can reflect its maturity level, the degree of recognition that market to company and amount of public information that investors can obtain.

Second, financing scale. In some degree, the bigger financing scale means the bigger company scale, large-scale company often establish a more completely and standard system in information disclosure. The better information disclosure system can reduce the degree of information asymmetry between company and investors, this will restrict opportunistic behavior to some extent and have a positive influence on IPO underpricing. This study use natural logarithm of financing amount to measure financing scale.

Third, first day price earnings ratio. To a certain extent, price earning ratio can be a measuring indicator of speculation degree, when the price earning ratio exceeds a certain value, the higher price earning ratio refers to the higher speculation degree. Price earning ratio have a big effect on the investors' selection and then influent IPO underpricing.

Fourth, first day turnover rate. This variable refers to the ratio of volume and issued amount, it reflect the frequency of investors trade new stocks. The high turnover rate means the investment deal is active, investors have a stronger desire of purchase. However, the high turnover rate always means a more specula- 
tive atmosphere and have bad influence on IPO underpricing.

Fifth, the lottery rate of online distribution. The lottery rate is connected with Financing volume of subscribe, it also reflect investors' recognition degree to the issue price and investors' mood. The lower lottery rate means the Larger amount of money, in this case, the investors who cannot purchase the new share will transfer their requirements to secondary market, this can make the stock price deviate from the actual value and increase the transaction price, then affect IPO underpricing.

Sixth, earnings per share. Generally speaking, earnings per share is the important index to measure investment value and risk, it also always be used to measure the management results of the company and as a important financial index to evaluate the company's profitability. This study choose the earnings per share of the previous year.

\subsection{Relationship of Venture Capital Investment and Second-Board Market IPO Underpricing}

This study chooses why this method not other econometric tools? Is this mean test enough? to test the IPO underpricing and its influence index.

\subsubsection{Relationship of Venture Capital and IPO Underpricing}

This study divided the 125 companies into two groups-have venture capital involved and the opposite, then compare the average value of the two sub-samples' IPO underpricing. The result is as follow:

Table 1 and Table 2 shows that, the average IPO underpricing of the companies which have venture capital involved is higher than the companies which don't have venture capital involved. In the Levene Test, F-sig is 0.973 , exceed the significance level 0.05 , so this study accept the assumption that the two groups' variance is equal. The T-sig is 0.131 , exceed the significance level 0.05 , so this

Table 1. Group statistics.

\begin{tabular}{ccccc}
\hline VC & N & Mean & Std. Deviation & Std. Error Mean \\
\hline Underpricing 1 & 105 & 0.30262406 & 0.225184737 & $\mathbf{0 . 0 2 1 9 7 5 7 8 0}$ \\
0 & 20 & $\mathbf{0 . 2 2 0 1 2 5 5 2}$ & $\mathbf{0 . 2 0 4 6 1 3 5 3 6}$ & $\mathbf{0 . 0 4 5 7 5 2 9 7 8}$ \\
\hline
\end{tabular}

Notes: group 1 is the company which have venture capital involved, the group 2 is the company which don't have venture capital involved.

Table 2. Independent samples test.

\begin{tabular}{|c|c|c|c|c|c|c|c|c|c|}
\hline & \multicolumn{2}{|c|}{$\begin{array}{l}\text { Levene's Test for } \\
\text { Equality of Variances }\end{array}$} & \multicolumn{7}{|c|}{ t-test for Equality of Means } \\
\hline & \multirow[t]{2}{*}{$\mathrm{F}$} & \multirow{2}{*}{ Sig. } & \multirow[t]{2}{*}{$\mathrm{t}$} & \multirow{2}{*}{ df } & \multirow{2}{*}{$\begin{array}{c}\text { Sig. } \\
\text { (2-tailed) }\end{array}$} & \multirow{2}{*}{$\begin{array}{c}\text { Mean } \\
\text { Difference }\end{array}$} & \multirow{2}{*}{$\begin{array}{l}\text { Std. Error } \\
\text { Difference }\end{array}$} & \multicolumn{2}{|c|}{$\begin{array}{c}\text { 95\% Confidence Interval } \\
\text { of the Difference }\end{array}$} \\
\hline & & & & & & & & Lower & Upper \\
\hline Equal variances assumed & 0.001 & 0.973 & 1.522 & 123 & 0.131 & 0.0825 & 0.05419 & -0.02478 & 0.18977 \\
\hline Equal variances not assumed & & & 1.625 & 28.501 & 0.115 & 0.0825 & 0.05076 & -0.02139 & 0.18639 \\
\hline
\end{tabular}


study accept the assumption of the null hypothsis of two independent sample's T test-the IPO underpricing have nothing to do with the venture capital. On the growth enterprise board, venture capital has no had significant effects on IPO underpricing, explain a little bit, is this conclusion surprised or against some theories

\subsubsection{Relationship between Venture Capital and Control Variable}

There are many factors that affect IPO underpricing, like the basic information of listed companies, market performance and shareholders. In order to ensure the accuracy of research result, this paper choose the variables that related to IPO underpricing as control variable, use independent-samples $\mathrm{T}$ test to compare the value, the purpose is to find the difference of financing scale, PE ratio, turnover rate, win a label rate and earnings per share.

From Table 3, in vc-backed sample, the values of price earnings ratio, turnover rate and earnings per share are higher than non-vc-backed sample. Meanwhile, each variable's significance level is less than 0.05 . These values means venture capital have no obvious influence on IPO underpricing.

\subsection{Relationship between the Characteristics of Venture Capital and IPO Underpricing}

The companies that have venture capital's support, the reputation, amount, and shareholding ratio of venture capital institution called the characteristics of venture capital. This paper use independent-samples T test, Spearman rank correlation analysis and Pearson product-moment correlation to research the relationship between venture capital and IPO underpricing. This chapter choose VCBacked sample-the 105 companies that have venture capital institution involved as research object.

Table 3. Relationship between venture capital and control variable.

\begin{tabular}{|c|c|c|c|c|}
\hline & \multicolumn{2}{|c|}{ Mean value } & \multirow[t]{2}{*}{ T-value } & \multirow[t]{2}{*}{ significance level } \\
\hline \multirow[b]{2}{*}{ operation time } & VC-Backed & 11.92250 & & \\
\hline & NON-VC-Backed & 12.71164 & -0.760 & 0.449 \\
\hline \multirow{2}{*}{$\begin{array}{l}\text { first day price } \\
\text { earnings ratio }\end{array}$} & VC-Backed & 30.98114 & \multirow{2}{*}{1.102} & \multirow{2}{*}{0.273} \\
\hline & NON-VC-Backed & 28.20900 & & \\
\hline \multirow{2}{*}{ financing scale } & VC-Backed & 19.68185 & \multirow{2}{*}{-0.969} & \multirow{2}{*}{0.335} \\
\hline & NON-VC-Backed & 19.80048 & & \\
\hline \multirow[b]{2}{*}{ first day turnover rate } & VC-Backed & 3.092736 & \multirow[b]{2}{*}{-0.04} & \multirow[b]{2}{*}{0.968} \\
\hline & NON-VC-Backed & 0.395905 & & \\
\hline \multirow{2}{*}{$\begin{array}{c}\text { the lottery rate } \\
\text { of online distribution }\end{array}$} & VC-Backed & 1.314509 & \multirow{2}{*}{-2.83} & \multirow{2}{*}{0.777} \\
\hline & NON-VC-Backed & 1.391680 & & \\
\hline \multirow{2}{*}{ earnings per share } & VC-Backed & 1.208829 & \multirow{2}{*}{1.287} & \multirow{2}{*}{0.200} \\
\hline & NON-VC-Backed & 0.98870 & & \\
\hline
\end{tabular}




\subsubsection{Relationship between the Reputation of Venture Capital Institution and IPO Underpricing}

This chapter choose independent-samples $\mathrm{T}$ test to research the relationship between the reputation of venture capital institution and IPO underpricing. For the companies in high reputation list, it's value of VC-Rep is 1, otherwise the value is 0 . The result is as follow:

From the mean of IPO underpricing, the value of VC-Rep-H sample is higher than VC-Rep-L sample. From the Table 4 and Table 5, we can know that in Growth Enterprises Market, the companies which have high reputation venture capital institution involved show a lower IPO underpricing, but this variable have a weak influence on IPO underpricing. So grandstanding theory haven't been confirmed on Growth Enterprises Market.

\subsubsection{Relationship between Amount of Venture Capital Institution and IPO Underpricing}

After consult the prospectus of 105 companies in VC-Backed sample, we can calculated out the amount of venture capital institution in each companies' shareholder list. Because of the amount of venture capital institution is discrete variable, this paper choose Spearman rank correlation analysis to research the relationship between amount of venture capital institution and IPO underpricing. The result is as follow Table 6.

We can find negative correlation between amount of venture capital institution and IPO underpricing, the coefficient is -0.14 , but Sig. (1-tailed) is 0.078 , this mean the relationship between amount of venture capital institution and IPO underpricing is insignificant.

\subsubsection{Relationship between Shareholding Ratio of Venture Capital Institution and IPO Underpricing}

This paper use Pearson product-moment correlation to research the relationship between shareholding ratio of venture capital institution and IPO underpricing, the result is as follow:

Table 4. Comparison of IPO underpricing.

\begin{tabular}{cccccc}
\hline Rep & & $\mathrm{N}$ & Mean & Std. Deviation & Std. Error Mean \\
\hline \multirow{2}{*}{ IPO underpricing } & 0 & 91 & 0.305923 & 0.2161072 & 0.0226542 \\
& 1 & 14 & 0.281179 & 0.2859546 & 0.0764246 \\
\hline
\end{tabular}

Table 5. Independent-samples test.

\begin{tabular}{|c|c|c|c|c|c|c|c|c|c|c|}
\hline & & \multicolumn{2}{|c|}{$\begin{array}{l}\text { Levene's Test for } \\
\text { Equality of Variances }\end{array}$} & \multicolumn{7}{|c|}{ t-test for Equality of Means } \\
\hline & & \multirow[t]{2}{*}{$\mathrm{F}$} & \multirow[t]{2}{*}{ Sig. } & \multirow[t]{2}{*}{$\mathrm{t}$} & \multirow[t]{2}{*}{$\mathrm{df}$} & \multirow{2}{*}{$\begin{array}{c}\text { Sig. } \\
\text { (2-taile d) }\end{array}$} & \multirow{2}{*}{$\begin{array}{c}\text { Mean } \\
\text { Difference }\end{array}$} & \multirow{2}{*}{$\begin{array}{l}\text { Std. Error } \\
\text { Difference }\end{array}$} & \multicolumn{2}{|c|}{$\begin{array}{l}\text { Confidence Interval } \\
\text { of the Difference }\end{array}$} \\
\hline & & & & & & & & & Lower & Upper \\
\hline \multirow{2}{*}{$\begin{array}{c}\text { IPO } \\
\text { underpricing }\end{array}$} & $\begin{array}{l}\text { Equal variances } \\
\text { assumed }\end{array}$ & \multirow{2}{*}{1.711} & \multirow{2}{*}{0.194} & 0.381 & 103 & 0.704 & 0.0247445 & 0.0649144 & -0.1039978 & 0.1534868 \\
\hline & $\begin{array}{l}\text { Equal variances } \\
\text { not assumed }\end{array}$ & & & 0.310 & 150.368 & 0.760 & 0.0247445 & 0.0797115 & -0.1448032 & 0.1942921 \\
\hline
\end{tabular}


Table 6. Correlations of Spearman.

\begin{tabular}{|c|c|c|c|c|}
\hline & & & $\begin{array}{c}\text { amount of } \\
\text { venture capital } \\
\text { institution }\end{array}$ & $\begin{array}{c}\text { IPO } \\
\text { underpricing }\end{array}$ \\
\hline \multirow{6}{*}{ Spearman's rho } & & Correlation Coefficient & 1.000 & -0.140 \\
\hline & $\begin{array}{l}\text { amount of venture } \\
\text { capital institution }\end{array}$ & Sig. (1-tailed) & - & 0.078 \\
\hline & & $\mathrm{N}$ & 105 & 105 \\
\hline & & Correlation Coefficient & -0.140 & 1.000 \\
\hline & IPO underpricing & Sig. (1-tailed) & 0.078 & - \\
\hline & & $\mathrm{N}$ & 105 & 105 \\
\hline
\end{tabular}

Table 7 show us a negative correlation between shareholding ratio of venture capital institution and IPO underpricing. The Sig. (1-tailed) is 0.040 , means a higher shareholding ratio of venture capital will lead to a lower IPO underpricing. This conclusions supported certification theory and supervision theory-the higher shareholding ratio of venture capital means a higher degree of participation that venture capital manage company, so venture capital institution can supervise company. But supervisory role only because the shareholding ratio of venture capital represent the ratio of reducing holding-shares after lock-up period. Investors in secondary market can forecast the loss because of reducing holding-shares, so they will not overestimate the value of stocks.

\subsection{Multivariate Regression Analysis of Venture Capital and IPO Underpricing}

This paper choose IPO underpricing as explained variable and use multivariate regression analysis to research the correlation between IPO underpricing and its influencing factor.

There are three model in this paper, model 1 is to explain the not only correlation, might also show some causal relationship? Between IPO underpricing and its influencing factor, model 2 is to explain the correlation between IPO underpricing and venture capital, model 3 is to analyze the correlation between IPO underpricing and venture capital's characteristics.

Model 1: $\mathrm{AUp}=\beta 0+\sum \beta \mathrm{i}{ }^{\star} \mathrm{C}$ variablesi $+\mathcal{E}$

Model 2: $\mathrm{AUp}=\beta 0+\beta 1{ }^{*} \mathrm{VC}+\sum \beta \mathrm{i}{ }^{*} \mathrm{C}$ variablesi $+\varepsilon$

Model 3: $\mathrm{AUp}=\beta 0+\beta 1{ }^{\star} \mathrm{VC}$ Rep $+\beta 2{ }^{\star} \mathrm{VCNum}+\beta 3{ }^{\star} \mathrm{VCShare}+\sum \beta 1{ }^{\star} \mathrm{C}$ variablesi $+\mathcal{\varepsilon}$

In model $1, \beta i(i=1,2, \ldots, 7)$ means the coefficient of each control variable and Cvariables i $(i=1,2, \ldots, 7)$ means control variables. In model $2, \beta_{1}$ means the degree of venture capital participate in company, and $\beta i(i=1,2, \ldots, 8)$ means the coefficient of each control variable. In model $3, \beta_{1}$ means the reputation of venture capital institution, $\beta_{2}$ means the amount of venture capital institution and $\beta_{3}$ means the shareholding ratio of venture capital institution. $\beta_{i}(i=4,5, \cdots \cdots, 10)$ means the coefficient of each control variable. 
Table 7. Correlations of Pearson.

\begin{tabular}{cccc}
\hline & IPO underpricing & $\begin{array}{c}\text { shareholding ratio of } \\
\text { venture capital institution }\end{array}$ \\
\hline IPO underpricing & Pearson Correlation & 1 & $-0.172^{*}$ \\
$\begin{array}{c}\text { Sig. (1-tailed) } \\
\text { shareholding ratio } \\
\text { of venture }\end{array}$ & Pearson Correlation & $-0.172^{*}$ & 0.040 \\
capital institution & Sig. (1-tailed) & 0.040 & 105 \\
\hline
\end{tabular}

${ }^{*}$ Correlation is significant at the 0.05 level (1-tailed).

\subsubsection{Can You Show the Results of 3 Regressions in One Table? To Make Comparison Easier. Pls Also Show $\mathbf{R}^{2}$ of F Stats}

From Table 8, we can know that there didn't show severe multicollinearity problem. Among the control variables, financing scale and lottery rate of online distribution have significant correlations with IPO underpricing. The coefficient of financing scale is -0.147 , means a negative correlation. On Growth Enterprises Market, the bigger financing scale means the bigger enterprise scale. Big enterprise have normal management, gained extensive attention of investors, these companies' information are more transparent, so these companies have a lower IPO underpricing. The coefficient of lottery rate of online distribution is -0.063 , means a negative correlation. The lower lottery rate of online distribution means the demand for these stocks exceeds the supply on the market. So these stocks will be deal frequently on the first day, this will lead to the transaction value of these stocks higher than it's actual value, and finally show a high IPO underpricing.

\subsubsection{Result of Model 2}

From Table 9, we can know that there didn't show severe multicollinearity. The coefficient of venture capital is 0.050 , which means a positive correlation. The company which has venture capital institutions involved always show a higher IPO underpricing, this can verify that certification theory and supervision theory didn't play a role on Growth Enterprises Market.

\subsubsection{Result of Model 3}

From Table 10, the reputation of venture capital institutions no coefficient with IPO underpricing, so grandstanding theory didn't play a role on Growth Enterprises Market.

\section{Conclusions}

After theoretical research and empirical analysis, the conclusions are as follow: first, certification theory and supervision theory didn't play a role on Growth Enterprises Market; second, the reputation of venture capital institutions have weak influence on IPO underpricing; third, the real reason of IPO underpricing is speculation and blindness in investment in secondary market. 
Table 8. Coefficient of Model 1.

\begin{tabular}{|c|c|c|c|c|c|c|c|}
\hline \multirow[t]{2}{*}{ Model } & \multicolumn{2}{|c|}{$\begin{array}{l}\text { Unstandardized } \\
\text { Coefficients }\end{array}$} & \multirow{2}{*}{$\begin{array}{c}\begin{array}{c}\text { Standardized } \\
\text { Coefficients }\end{array} \\
\text { Beta }\end{array}$} & \multirow[t]{2}{*}{$\mathrm{t}$} & \multirow[t]{2}{*}{ Sig. } & \multicolumn{2}{|c|}{$\begin{array}{l}\text { Collinearity } \\
\text { Statistics }\end{array}$} \\
\hline & B & Std. Error & & & & Tolerance & VIF \\
\hline (Constant) & 3.147 & 0.800 & - & 3.932 & 0.000 & - & - \\
\hline operation time & 0.002 & 0.004 & 0.043 & 0.511 & 0.611 & 0.906 & 1.104 \\
\hline price earnings ratio & 0.000 & 0.002 & 0.017 & 0.168 & 0.867 & 0.648 & 1.542 \\
\hline financing scale & -0.147 & 0.041 & -0.330 & -3.568 & 0.001 & 0.761 & 1.314 \\
\hline turnover rate & 0.006 & 0.061 & 0.009 & 0.097 & 0.923 & 0.811 & 1.233 \\
\hline $\begin{array}{c}\text { lottery rate of } \\
\text { online distribution }\end{array}$ & -0.063 & 0.019 & -0.312 & -3.250 & 0.002 & 0.709 & 1.411 \\
\hline earnings per share & 0.070 & 0.031 & 0.219 & 2.230 & 0.028 & 0.678 & 1.476 \\
\hline
\end{tabular}

Table 9. Coefficient of Model 2.

\begin{tabular}{|c|c|c|c|c|c|c|c|}
\hline \multirow[t]{2}{*}{ Model } & \multicolumn{2}{|c|}{$\begin{array}{l}\text { Unstandardized } \\
\text { Coefficients }\end{array}$} & \multirow{2}{*}{$\begin{array}{c}\begin{array}{c}\text { Standardized } \\
\text { Coefficients }\end{array} \\
\text { Beta }\end{array}$} & \multirow[t]{2}{*}{$\mathrm{t}$} & \multirow[t]{2}{*}{ Sig. } & \multicolumn{2}{|c|}{$\begin{array}{c}\text { Collinearity } \\
\text { Statistics }\end{array}$} \\
\hline & $\mathrm{B}$ & Std. Error & & & & Tolerance & VIF \\
\hline (Constant) & 2.993 & 0.816 & - & 3.666 & 0.000 & - & - \\
\hline operation time & 0.003 & 0.004 & 0.049 & 0.576 & 0.566 & 0.901 & 1.109 \\
\hline price earnings ratio & $-5.683 \mathrm{E}-5$ & 0.002 & -0.003 & -0.026 & 0.980 & 0.624 & 1.604 \\
\hline financing scale & -0.141 & 0.042 & -0.316 & -3.367 & 0.001 & 0.742 & 1.348 \\
\hline turnover rate & 0.008 & 0.061 & 0.012 & 0.133 & 0.895 & 0.810 & 1.235 \\
\hline $\begin{array}{c}\text { lottery rate of } \\
\text { online distribution }\end{array}$ & -0.061 & 0.019 & -0.301 & -3.117 & 0.002 & 0.699 & 1.430 \\
\hline earnings per share & 0.062 & 0.032 & 0.196 & 1.940 & 0.055 & 0.641 & 1.561 \\
\hline venture capital & 0.050 & 0.051 & 0.082 & 0.972 & 0.333 & 0.921 & 1.086 \\
\hline
\end{tabular}

Table 10. Coefficient of Model 3.

\begin{tabular}{|c|c|c|c|c|c|c|c|}
\hline \multirow[t]{2}{*}{ Model } & \multicolumn{2}{|c|}{$\begin{array}{l}\text { Unstandardized } \\
\text { Coefficients }\end{array}$} & \multirow{2}{*}{$\begin{array}{c}\begin{array}{c}\text { Standardized } \\
\text { Coefficients }\end{array} \\
\text { Beta }\end{array}$} & \multirow[t]{2}{*}{$\mathrm{t}$} & \multirow[t]{2}{*}{ Sig. } & \multicolumn{2}{|c|}{$\begin{array}{c}\text { Collinearity } \\
\text { Statistics }\end{array}$} \\
\hline & B & Std. Error & & & & Tolerance & VIF \\
\hline (Constant) & 2.761 & 1.060 & - & 2.604 & 0.011 & - & - \\
\hline operation time & -0.001 & 0.005 & -0.024 & -0.249 & 0.804 & 0.878 & 1.140 \\
\hline price earnings ratio & 0.000 & 0.002 & 0.013 & 0.112 & 0.911 & 0.617 & 1.621 \\
\hline financing scale & -0.123 & 0.055 & -0.258 & -2.219 & 0.029 & 0.626 & 1.597 \\
\hline turnover rate & 0.003 & 0.071 & 0.004 & 0.038 & 0.969 & 0.793 & 1.261 \\
\hline $\begin{array}{c}\text { lottery rate of } \\
\text { online distribution }\end{array}$ & -0.063 & 0.022 & -0.316 & -2.0817 & 0.006 & 0.671 & 1.490 \\
\hline earnings per share & 0.061 & 0.038 & 0.198 & 1.0605 & 0.112 & 0.555 & 1.802 \\
\hline reputation & -0.017 & 0.064 & -0.026 & -0.272 & 0.786 & 0.897 & 1.115 \\
\hline amount & -0.002 & 0.013 & -0.021 & -0.164 & 0.870 & 0.517 & 1.936 \\
\hline shareholding ratio & 0.000 & 0.001 & -0.095 & -0.804 & 0.423 & 0.602 & 1.660 \\
\hline
\end{tabular}


To cure the above problems, there are four advices: First, improve the quality of venture capital institutions. As a venture capital institution, it needs to pay close attention to long-term development of enterprise, like cultivate professional personnel, provide value-added services for the enterprise. Second, perfect evaluation system of the reputation of venture capital institution. A perfect evaluation system can urge venture capital institutions to constantly improve its ability. This will be good for establishing positive market competition mechanism. Third, it can improve the quality of listed company. Before choosing a venture capital institution, the company needs to measure its circumstance and the background of venture capital institution. After getting the venture capital, the company needs to seek help of venture capital institution actively to improve management mode, innovative ability and service level. Fourth, instruct investors to be rational. Investors need to accumulate investment knowledge and cultivate logical thought, this can help reduce the blind investment behavior.

\section{References}

Amit, R., Glosten, L., \& Muller, E. (1990). Entrepreneurial Ability, Venture Investment, and Risk Sharing. Management Science, 36, 1232-1245.

https://doi.org/10.1287/mnsc.36.10.1233

Barry, C. B., Muscarella, C. J., Peavy, J. W. et al. (1990). The Role of Venture in the Creation of Public Companies. Journal of Financial Economics, 27, 447-471. https://doi.org/10.1016/0304-405X(90)90064-7

Gompers, P. A. (1996). Optimal Investment, Monitoring, and the Staging of Venture Capital. Journal of Finance, 50, 1461-1489.

https://doi.org/10.1111/j.1540-6261.1995.tb05185.x

Megginson, W., \& Weiss, K. (1991). Venture Capitalist Certification in Intial Public Offerings. The Journal of Finance, 46, 879-903.

https://doi.org/10.1111/j.1540-6261.1991.tb03770.x

\footnotetext{
Scientific Research Publishing

Submit or recommend next manuscript to SCIRP and we will provide best service for you:

Accepting pre-submission inquiries through Email, Facebook, LinkedIn, Twitter, etc. A wide selection of journals (inclusive of 9 subjects, more than 200 journals)

Providing 24-hour high-quality service

User-friendly online submission system

Fair and swift peer-review system

Efficient typesetting and proofreading procedure

Display of the result of downloads and visits, as well as the number of cited articles

Maximum dissemination of your research work

Submit your manuscript at: http://papersubmission.scirp.org/

Or contact jfrm@scirp.org
} 